\title{
Morphoquantitative Analysis of the Intraepithelial Neoplasic Uterine Cells by Computer Image System
}

\author{
Análisis Morfocuantitativo de las Células Neoplásicas Intraepiteliales \\ Uterinas por Sistema Computarizado \\ "Jacqueline Silva Brito Lima; ${ }^{* * *}$ Alexandre Motta Bittencourt; ${ }^{* * * *}$ Carlos Eduardo de Queiroz Lima;
${ }^{* * * *}$ Diógenes Luis da Mota; ${ }^{* * * * * *}$ Ana Maria de Ataíde Romaguera \& ${ }^{* * * *}$ Luiz Lúcio Soares da Silva
}

LIMA, B. J. S; BITTENCOURT, A. M.; LIMA, Q. C. E.; MOTA, D. L.; ROMAGUERA, A. A. M. \& DA SILVA, S. L. L. Morphoquantitative analysis of the intraepithelial neoplasic uterine cells by computer image system. Int. J. Morphol., 26(1):93-98, 2008.

SUMMARY: The purpose of the present research was to detect the DNA variations by Feulgen stained chromatin and the packing degree of the cervical chromatin in the clinical cases of human uterine carcinomas. Scanning microphotometry was carried out on slides prepared from block Feulgen-stained. Accurate control procedures were performed using normal human cell nuclei. The cervical cells was morphometric studied using the Image Lab System for citologic classification. The overall diagnostic accuracy for neoplasia type I (CIN I) and type II (CIN II), demonstrated by stain interpetration values of a sensitive detection of DNA neuroploidy and a significant difference between the two groups in scanning static cytophotometry.

KEY WORDS: Cervix; DNA; Cervical Cancer; Morphometry.

\section{INTRODUCTION}

Neoplasias of the uterine cervix in developed and under-developed countries are diagnosed in 171.640 women. In Brazil, the cancer of uterine cervix is believed to be the third most common amongst women, just behind skin cancer (not melanoma) and breast cancer. In the NorthEastern part of Brazil its occurrence is 30.2 per 100.00 inhabitants, $10 \%$ of which are malignant (Ministério da Saúde, 2005).

The disease starts at an early age and moves up gradually, thus allowing a better diagnostic according to Lima et al. (1999), Cramer \& Cutler (1974) who came up with 15.6 years of time between both the initial injury and the phase clinically diagnosed. Several factors are responsible for the cancer of uterine cervix and, most of them are possibly from epithelial tissues lesions, Pappa et al. (2006); or now caused by papilloma virus (HPV) (Lopes et al., 2002). Nowadays, various methods are used to have a better diagnosis of these injuries (Papanicolaou \& Traut,
1943; Coplesson et al., 1992) but, it was back in 1932 that Broders (1932) introduced the term carcinoma in situ used until now, and based upon architectural disturbances in both nuclear abnormalities and indifferenciation.

To show evidence of difficulties during diagnosis, Richard (1967) proposed that epithelial alterations of the uterine cervix, be divided in three levels used as intraepithelial neoplasias (CIN) I, II, and III for those more serious. Although it's known that the numerous diagnosed dysplasias by cytomorphology and histology are insufficient to detect the preventive malignancy even with a constant preoccupation of inner controls, Amaral et al. (2003), Pittoli et al. (2003) and Böcking et al. (1985) think DNA quantification can be used in different techniques such as Giemsa, Toluidine Blue, Gallocyanine (stain methods), and other coloration techniques. Böhm (1968) efforts have been made towards automatic diagnostic of tumors by flow cytometry to measure nuclear DNA.

\footnotetext{
* Depto. de Anatomia da UFAL, Pós-Graduation of Morphology CCB Universidade Federal de Pernambuco, Brasil.

** Depto.de Anatomia UFPE, Pós-Graduation of Morphology CCB Universidade Federal de Pernambuco, Brasil.

**** Depto. de Ciências Farmacêuticas U.F.PE, Pós-Graduation of Morphology CCB Universidade Federal de Pernambuco, Brasil.

***** Depto. de Histologia U.F.PE, Pós-Graduation of Morphology CCB Universidade Federal de Pernambuco, Brasil.

****** Depto. de Biologia da UPE, Pós-Graduation of Morphology CCB Universidade Federal de Pernambuco, Brasil.
} 
Morphologic techniques to classify malignant tumors are considered subjective and non reliable in their reproduction (Böcking \& Auffermann, 1982). Objective techniques are necessary to accurately show a prognosis in case of cancer for the chosen therapy be both adequate and solely for that subject. DNA study, with no doubt, is the ideal parameter to be used as the condition for prognosis tests (Feulgen \& Rossenbeck, 1924; Böcking \& Auffermann).

Our purpose was to quantify possible DNA mutations through a computerized analysis of images along with Feulgen \& Rossenbeck's histochemic reaction.

\section{MATERIAL AND METHOD}

A total of 103 uterine cervix biopsies from subjects between 15-66 years old (32 years on average) were used, with differences in cross-breeding as to active sexual life, not using hormonal adjustment, marital status as married, single and widows (facts from medical files), all this collected at the University Hospital and the Hospital of Sugar and Alcohol Agro-Industry in Alagoas, and the Hospital of Cancer in Pernambuco). These subjects were divided in two groups, following cervical intraepithelial neoplasias diagnostic of the cervix of uterus in level I (CIN I) and level II (CIN II), Tables I and II.

Table I. Benign cervical intraepithelial neoplasias diagnostic (CIN I) subjects in North-Eastern Brazil.

\begin{tabular}{llll} 
Neoplasia & Marital Status & Race \\
\hline \multirow{3}{*}{ Level I ( CIN I) } & Single & 08 & White \\
& & 00 & Black \\
& Married & 37 & White \\
& Widows & 00 & Black \\
& & 00 & White \\
& Unknow & 09 & \\
Total & & 56 &
\end{tabular}

Table II. Moderate cervical intraepithelial neoplasias diagnostic (CIN II) subjects in North-Eastern Brazil.

\begin{tabular}{llll} 
Neoplasia & Marital Status & Race \\
\hline \multirow{3}{*}{ Level II ( CIN II) } & Single & 08 & White \\
& & 03 & Black \\
& Married & 32 & White \\
& Widows & 02 & Black \\
& & 01 & White \\
& Unknow & 00 & Black \\
Total & & 47 &
\end{tabular}

All diagnoses were confirmed, those with CIN III, incompatible diagnosis and incomplete or unknown facts being ruled out.

The material of blocks handed over were slice on $5 \mu \mathrm{m}$ of width (Spencer microtome), colored with hematoxiline eosine for histology analysis and Feulgen \&Rossenbeck histochemical reaction while being bleached with Fast-Green to quantify possible DNA alterations. Typical cells, mainly lymphocytes, were used as control colored with hematoxiline-eosine.

After Feulgen \& Rossenbeck histochemic reaction, eight to fifteen areas were analyzed on slide, reaching a total of one hundred cells, then captured by the Image-Lab software connected to microscope (Leica DMLS), video camera (Samsung 410-SHC-NAD), computer (Penthium III) for analysis and morphometric quantification. The equipment was balanced and the sequenced readings using both Haroske et al. (1994) and Giroud \& Montmassou (1989) security measure. The facts obtained were submitted to statistics analysis.

\section{RESULTS}

Several slides and blocks $(61.17 \%)$ were disregarded due to a failure to marital status identification, race, age and sexual orientation; with tissues incorrectly wrapped and misplaced; with incompatible diagnosis, such as slides with low optic resolution. Thus a total of forty subjects in group 1 and 2 remained, representing (38.83\%) of the sample (Tables III and IV).

Table III. Benign cervical intraepithelial neoplasias (CIN I) diagnostic subjects in North-Eastern Brazil.

\begin{tabular}{llcl} 
Neoplasia & Marital Status & Race \\
\hline \multirow{3}{*}{ Level I ( CIN I) } & Single & 00 & White \\
& & 04 & Black \\
& Married & 00 & White \\
& & 14 & Black \\
& Widows & 00 & White \\
& & 02 & Black \\
Total & Unknow & 00 & \\
& & 20 &
\end{tabular}

It was impossible to establish any fact as to racial aspects because de casuistic has incomplete information, such as neoplasias occurrence in ages. For neoplasias disparity levels (light and moderate) using lymphocyte (Fig. 1), we 
can observe in the level light, CIN I (Fig. II) a higher intensity between channels 2.3 to 6.8 . In Fig. III, as to neoplasias intensity in moderate level (CIN II) there was a higher prevalent in channels 1 to 5 , having a modest superposition in some cases.

Table IV. Moderate cervical intraepithelial neoplasias diagnostic (CIN II) subjects in North-Eastern Brazil.

\begin{tabular}{llll} 
Neoplasia & Marital Status & Race \\
\hline \multirow{3}{*}{ Level II ( CIN II) } & Single & 00 & White \\
& & 02 & Black \\
& Married & 02 & White \\
& Widows & 00 & Black \\
& & 00 & White \\
& Unknow & 00 & \\
Total & & 20 &
\end{tabular}

Fig. 1. Lymphocytes intensity distribution in several channels in female subjects with cervix of uterus neoplasias diagnostic.

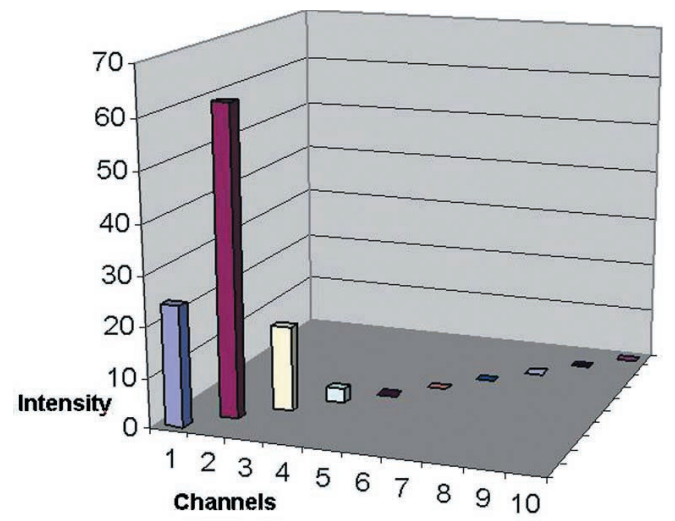

Fig. 2. Benign level of Intensity Prevalence in subjects with cervical intraepithelial neoplasia (CIN I) diagnostic.

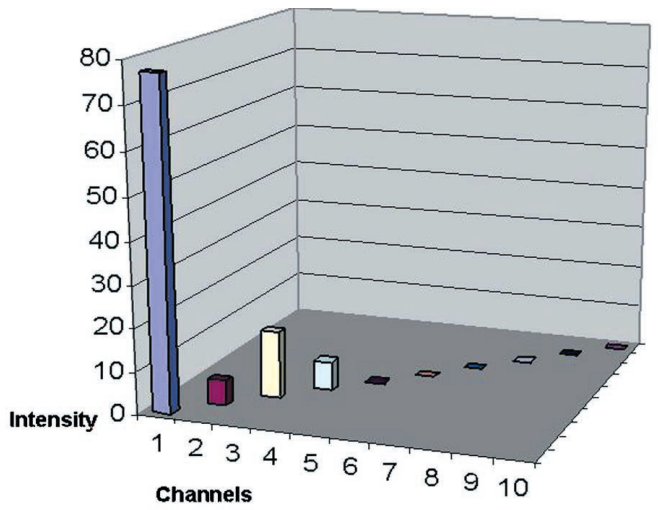

Fig. 3. Moderate level of intensity prevalence in subjects with cervical intraepithelial neoplasia (CIN II) diagnostic.
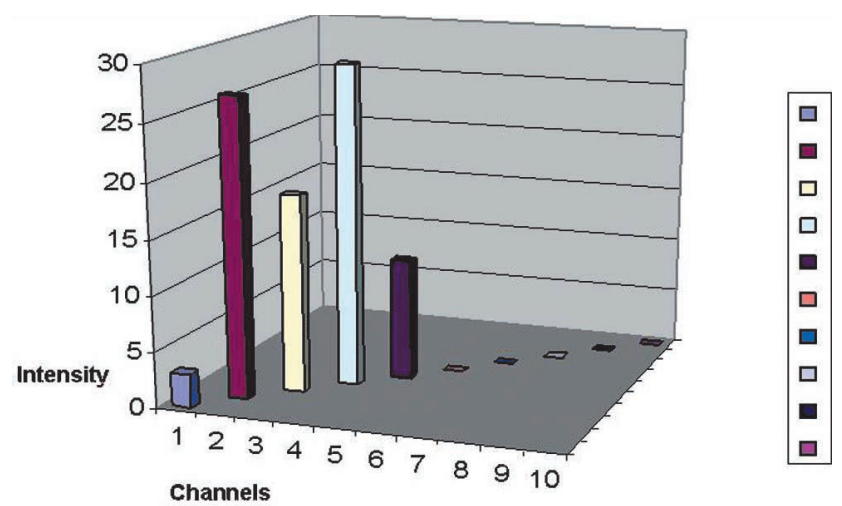

\section{DISCUSSION}

Existing difficulties in having a correct diagnostic, mainly the malignity initial phase, as for morphology aspects in relation with DNA nucleus, was a first found. In fact, they made us disqualify several subjects' material $(61.1 \%)$ for having a totally irregular distribution of chromogen results in diverse nucleus cells and a major intensity in a specific place, perhaps, due to the different fixing agents during impregnation method (Hanselaar et al., 1992). The usage of different fixing agents with different fixation methods shows some varieties about chromogen intensity in the ionic hydrogen concentration and the hydrolise time in Feulgen's reaction (Böhm; Böhm et al., 1968) that could interfere in the condensation of chromatin's spatial distribution and, apart from tracking the DNA, does the same with proteins (Stedman \& Stedman, 1950), Umayahara et al. (2002). Meanwhile, uncharacteristic DNA distributions, for some authors, in comparison with results from the epithelial of the uterine cervix cytrometry and its DNA, aren't an early malignity diagnostic method, Haroske et al. (2001), Ishikawa et al. (2002). Most of them consider aneuploidia as a malignity factor (Bollmann, 2003).

Level I (CIN I) neoplasias, we believe, can be subjected to different interpretations, based upon difficulties for, most dysplasia and malignity levels are detected through morphologic monitoring. Normally, degeneratives are followed by uncertainties due to a lack of confirmation in cells differentiations outset. Benign dysplasia lesions (CIN I) aren't easily identified, mainly because the change to malignant lacks observation (Böcking \& Hilgarth, 1983; Zhang et al., 2005). To detect cancerous cells the usage of histochemic technique linked with cytometry is undoubtedly 
valid (Fu et al., 1981; Böcking \& Hilgarth; Wied et al., 1996). The advantage to link these methodologies is the confirmation of the beginning of lesions, even though the subject doesn't show dysplasia during observation routine, given aneuploid cells synonymous with malignity (Auffermann \& Böcking, 1983, Böcking et al., 1984; Sápi et al., 2005).

Our studies reveal a different concentrations in DNA cells distribution, as to moderate dysplasia (CIN II) indication and morphologic diagnostic, in opposition with those with dysplasia in benign level (CIN I), leading to a possible observation of the beginning of a lesion as observed by Böcking et al. (1984, 1985). According to Saccomano (1982), lesions considered moderate dysplasias (CIN II) change to carcinoma in situ within eight years. Although morphologic evidences of malignity are obvious, when the carcinoma in situ stage occurs, aneuploid cells presence in benign dysplasia (CIN I), possibly is an indication of pre-cancerous cells. Böcking et al. (1985) and Méhes et al. (2004) believe demonstration of DNA ploidy can be used as a quality control in cytology and a morphologic observation in histology.
Histochemic techniques is common in the initial diagnostic of the uterine cervix pathologies and neoplasias (Böcking \& Chatelain, 1992; Pinho \& Mattos, 2002). Meanwhile, a good technique usage in DNA proof needs knowledge, standardization from the beginning of the material acquisition and its fixation, to the histochemic marker and reading from computerized equipments, to get precise diagnostics (Zuna et al., 2002). When we compared our findings with Arcuri et al. (2002) and Schoolland et al. (2002), we found a huge percentage of unused material, for failure to reach a proof of basic conditions, or simply having mistaken diagnostics. We know, public hospitals have different financing cycles in a year, thus, usually allowing a usage of different fixing agents, difficulties in storage and handling so, standardizing the beginning of the process is essential independently from a technique to be used.

ACKNOWLEDGMENTS. We'd like to thank directors from «Hospitais Universitários e da Agro-indústria do Açucar do Estado de Alagoas», from «Hospital do Câncer de Pernambuco» and the technician Alex Benício for his time and support to our research.

LIMA, B. J. S; BITTENCOURT, A. M.; LIMA, Q. C. E.; MOTA, D. L.; ROMAGUERA, A. A. M. \& DA SILVA, S. L. L. Análisis morfocuantitativo de las células neoplásicas intraepiteliales uterinas por sistema computarizado. Int. J. Morphol., 26(1):93-98, 2008.

RESUMEN: La investigación tuvo como objetivo detectar las posibles variaciones del DNA en el núcleo de las células marcadas por la reacción histoquímica de Feulgen en individuos con diagnóstico de neoplasias intraepiteliales de grados I y II del cuello uterino. La microcitometría fue realizada en láminas provenientes de hospitales universitarios y estatales, sometidas a reacción de Feulgen y analizadas en el sistema de imagen (Image Lab) para cuantificación. Los resultados encontrados entre las células neoplásicas de grado I (NIC I) y del grado II (NIC II) demostraron que el método es sensible y eficiente en la cuantificación entre las diferentes clasificaciones, ayudando así en los diagnósticos de las lesiones del cuello uterino en su fase inicial.

PALABRAS CLAVE: Cuello Uterino; DNA; Cáncer Cervical; Morfometría.

\section{REFERENCES}

Amaral, R. G. G.; Santos, S. H.; Catharino, J. M.; Silva, L. C.; Westin, M. C.; Cotta, C.; Trevisan, M.; Hardy, E. \& Zeferino, L. C. Revisão rápida de esfregaços cervicais como método de garantia interna de qualidade. J. Bras. Patol. Méd. Lab., 39(2):151-5, 2003.

Arcuri, R. A; Cunha, K. C.; Alves, E. C.; Castro, A. A.; Maciel, R. A; Rosmanino, A. C.; Silva , P. L. \& Xavier, G. C. Controle interno de citopatologia ginecológica: um estudo de 48.355 casos. Rio de Janeiro. J. Bras. Patol. Méd. Lab., 38(2):141-7, 2002.

Auffermann, W. \& Böcking, A. Schenelle DNSZytophotometrie in der troutine mit dem LEITZ TASplus. Verth. Dtsch. Ges. Pathol., 67:707-13, 1983.
Böcking, A.; Adler, C. P.; Common, H. H.; Hilgarth, M.; Grazen, B. \& Auffermann, W. Algorithm for a DNAcytophotometric diagnosis and grading of malignancy. Analyt. Quant. Cytol., 6:1-8,1984.

Böcking, A. \& Auffermann, W. Algorithm for DNACytophotometric diagnosis and grading of malignancy. Verh. Dtsch. Ger. Pathol., 66:540-7,1982.

Böcking, A.; Auffermann, W.; Vogel, H.; Schondorff, G. \& Goebbels, R. Diagnosis and grading of malignancy of squamous epithelial lesions of the larynx with DNAcytophometriy. Cancer, 56:1600-4, 1985.

Böcking, A. \& Chatelain, R. Diagnostic and prognostic value 
of DNA cytometry in ginaecologic cytology. Anal. Quant. Cytol. Histol., 11:177-86, 1992.

Böcking, A. \& Hilgarth, M. Beurteilung der prospektiven malignitat zervikaler dysplasien durch DNSZytophotometrie. XIII Deutscher Kongress fur Zytologie, Frieburg, 1983.

Böhm, H. Einfluss der fixierung und der säurekoncentration auf die feulgenhydrolyse bei 280.C. Histochemie, 14:2001-211, 1968.

Böhm, H.; Sprenger, E.; Schlüter, G. \& Sandritter, W. Proportionalitäts fehler bei der feulgen hydrolyse. Histochemie, 15:194-203,1968.

Bollmann, R.; Mehes, G. \& Torka, R. HPV typing and DNA ploidy determination in squamous intraepithelial lesions (SIL) in liquid fixed cytological samples. Cancer, 99:57-62, 2003.

Broders, A. Carcinoma in situ contrasted with begnin penetrating epithelium. JAMA, 99:20-4, 1932.

Coppleson, M.; Atkinson, K. H. \& Dalrymple, J. C. Cervical squamous and glandular intraepithelial neoplasia: clinical features and review of management. In: Gynaecologic Oncology, $2^{\text {nd }}$ ed. Coppleson, M. editor. New York, Churchill Livingstone, 1992. pp. 595-7.

Cramer, D. W. \& Cutler, S. J. Incidence and histopathology of malignancies of the genital female organs in the United States. Am. J. Gynecol., 118:443-9, 1974.

Feulgen, R. \& Rossenbeck, H. Mikroskopisch-chemicher Nachweis einer nucleinsaure von typus der thymonucleinsaure und die darau beruhende elective farbung von Zellkernen in mikroskopischer preparaten. Hope-Seylers. Z. Physiol. Hanselaar Chem., 135:203$48,1924$.

Fu, Y. S.; Reagen, J. W. \& Richard, R. M. Definition of precursors. Gynecol. Oncol., 12:220-31,1981.

Giroud, F. \& Montmassou, M. P. Reavaluation of optimal Feulgen reaction for automated cytology: Influences of fixations. Analyt. Quant. Cytol. Histol., 11:87-95, 1989.

Hanselaar, A. G.; Vooijs.G. P.; Mayall, B. H.; Pahlplatz, M. M. \& Van't Hof-Grootenboer, A. E. DNA changes in progressive cervical intraepithelial neoplasia. Anal. Cell Pathol., 4(4):315-24,1992.
Haroske, G.; Baak, J. P. A.; Danielsen, H.; Giroud, F.; Gschwendtner, A.; Oberholzer, M.; Reith, A.; Spieler, P. \& Böcking, A. Fourth update ESACP consensus report on diagnostic DNA image cytometry. Anal. Cell Pathol., 23(2):89-95, 2001.

Haroske, G.; Meyer, W.; Dimmer, V.; Kunze, K. D. \& Theissig, F. Feasibility and limitations of a cytometric DNA ploidy analysis procedure in tissue sections. Zentralbl. Pathol., 139(6):407-17, 1994.

Ishikawa, F.; Saito, N; Koda, K.; Takiguchi, N.; Oda, K.; Suzuki, M.; Nunomura, M.; Sarashina, H. \& Miyazaki, M. Nuclear morphometric analysis of T2 lesions of the rectum-a simple, reproducible method for predicting malignancy potential. Am. J. Surg., 183(6):686-91, 2002.

Lima, G. R; Gebrim, L. H.; Oliveira,V. C. \& Martins, N. V. Ginecologia Oncológica. São Paulo, Atheneu, 1999.

Lopes, C. F.; Thiesen, K. \& Hass, P. Avaliação do diagnóstico citológico cérvico vaginal no hospital de guarnição de Florianópolis(HguFl). Newslab., 52:98-110, 2002.

Méhes, G.; Speich, N.; Bollmann, M. \& Bollmann, R. Chromosomal aberrations accumulate in polyploid cells of high-grade squamous intraepithelial lesions (HSIL). Pathol. Oncol. Res., 10(3):142-8, 2004.

Ministério da Saúde. Instituto Nacional de Câncer, Secretaria Nacional de Assistência a Saúde. Estimativa e Mortalidade por Câncer no Brasil. http//:inca.gov.br, Rio de Janeiro, 2005.

Papanicolaou, G. N. \& Traut, H. F. Diagnosis of uterine cancer by the vaginal smear. New York, Common Wealth Fund, 1943.

Pappa, I. K. ; Choleza, M.; Markaki, S. Giannikaki, E.; Kyroudi, A.; Vlachos, G.; Voulgaris, Z. \& Anagnou, N. P. Consistent absence of BRAF mutations in cervical and endometrial cancer despite KRAS mutation status. Gynecologic Oncology, 100:596-600, 2006.

Pinho, A . A. \& Mattos, M. C. Validade da citologia cervicovaginal na detecção de lesões pré-neoplásicas e neoplásicas de colo do útero. J. Bras. Patol. Méd. Lab., 38(3):225-31, 2002.

Pittoli, J. E.; Mello, E. S.; Pereira, S. M. Maeda, M. Y.; Utagawa, M. L.; Celestino, J. D. \& Loreto, C. D. I Revisão de esfregaços vaginais negativos em pacien- 
LIMA, B. J. S; BITTENCOURT, A. M.; LIMA, Q. C. E.; MOTA, D. L.; ROMAGUERA, A. A. M. \& DA SILVA, S. L. L. Morphoquantitative analysis of the intraepithelial neoplasic uterine cells by computer image system. Int. J. Morphol., 26(1):93-98, 2008.

tes com lesões intra-epiteliais de alto grau. J. Bras. Patol. Méd. Lab., 39(3):219-21, 2003.

Richard, R. M. Natural history of cervical intraepithelial neoplasia. Clinical Obstet. Gynecol., 10:784, 1967.

Saccomano, G. The contribution of the uranium miners to lung câncer histogenesis. Recent Results Cancer Res. 82:43-52, 1982.

Sápi, Z.; Pápai, Z.; Hruska, A.; Antal, I.; Bodó, M. \& Orosz, Z. Her-2 oncogene amplification, chromosome 17 and DNA ploidy status in synovial sarcoma. Pathol. Oncol. Res., 11(3):133-8, 2005.

Schoolland, M.; Allpress, S. \& Sterret, G. F. Adenocarcinoma of the cervix. Cancer, 96(1):5-13, 2002.

Stedman, E. \& Stedman, E. The cytological interpretation of the Feulgen reaction. Bioch. J., 47:508-12, 1950.

Umayahara, K.; Numa, F.; Suehiro ,Y.; Sakata, A.; Nawata, S.; Ogata, H.; Suminami, Y.; Sakamoto, M.; Sasaki, K. $\&$ Kato, H. Comparative genomic hybridization detects genetic alterations during early stages of cervical cancer progression. Genes Chromosomes Cancer, 33(1):98-102, 2002.

Wied, G. L.; Messina, A. M . \& Rosenthal, E. Comparative quantitative DNA-measurements of Feulgen-stained cervical epithelia cells. Acta Cytol., 10:31-7, 1996.

Zhang, J. M.; Hoshimoto, M. ; Kawai, K.; Murakumo, Y.; Sato, T.; Ichihara, M.; Nakamura, S. \& Takahashi, M. CD109 expression in squamous cell carcinoma of the uterine cervix. Pathol. Int., 55(4):165-9, 2005.

Zuna, R. E.; Sienko, A.; Lightfoot, S. \& Gaiser, G. Cervical smear interpretations in women with a histologic diagnosis of severe dysplasia: factors associated with discrepant interpretations. Cancer, 96(4):218-24, 2002.
Correspondence to:

Prof. Alexandre Motta Bittencourt

Rua Bruno Veloso N¹40/502

Boa Viagem

CEP - 51021-280

Recife, PE

BRASIL

Email: amb@ufpe.br

Received: 20-07-2007

Accepted: 03-12-2007 